\title{
NARROWING THE GAP IN THE EUROPEAN UNION: FROM UTOPIA TO PRAGMATISM
}

\author{
Ioana-Sorina MIHUȚ ${ }^{\text {a* }}$, Mihaela LUȚAȘ ${ }^{\mathrm{b}}$, \\ Sorin-Augustin CÂLEA ${ }^{\mathbf{c}}$
}

a), b), c) Babeș-Bolyai University, Faculty of Economics and Business Administration, Cluj-Napoca, Romania

Please cite this article as:

Article History:

Mihuț, I.S., Luțaș, M. and Câlea, S.A., 2020. Received: 10 October 2019 Narrowing the gap in the European Union: From Accepted: 31 March 2020 utopia to pragmatism. Review of Economic Studies and Research Virgil Madgearu, 13(1), pp.75-91.

doi: 10.24193/RVM.2020.13.53.

\begin{abstract}
The debate regarding the challenges the European Union is facing nowadays is a major topic of interest in the context of reshaping the borders of this community. The massive waves of "Eurosceptic" behaviours along with trade wars and migration flows are top priorities for the current institutional framework. Despite the overall objective of the European Union, namely assuring the sustainable convergence and economic development of all its Member States, the achievement of it was highly questioned by the recent political conflicts. The duty to respond in an efficient manner to the economic, but more importantly to the political risks, lies in the hands of the European institutions and into their ability to conduct what we generally refer to as a "good governance process". The main purpose of this article is to analyse whether the political stability and the democracy component, influence the economic growth trends and at the same time generates transformations in terms of migration waves.
\end{abstract}

Key words: European Union; political stability; economic growth; control of corruption

JEL Classification: $\mathrm{F}_{5}$; F22; O52

(C) 2020 Alma Mater Publishing House. All rights reserved.

* Corresponding author. E-mail address: ioana.mihut@econ.ubbcluj.ro. 
Review of Economic Studies and Research Virgil Madgearu, 2020, 13(1)

\section{References:}

1. Aisen, A. and Veiga., F., 2011. How does political instability affect economic growth? European Journal of Political Economy, 29, [online] Available at: https://doi.org/10.1016/j.ejpoleco. 2012.11.001.

2. Barro, R., 1991. Economic growth in a cross section of countries. The Quarterly Journal of Economics, 106(2), pp.407-443.

3. Boujelbene, Y. and Baklouti, N., 2017. An econometric study of the role of the political stability on the relationship between democracy and economic growth. Panoeconomicus, Advance online publication, [online] Available at: <https://panoeconomicus.org/index.php/ jorunal/article/view/526> [Accessed 10.08.2019].

4. Burkhart, R.E. and Lewis-Beck, M.S., 1994. Comparative democracy: the economic development thesis, The American Political Science Review, 88(4), pp.903-910.

5. Câlea, S., Deceanu, L., Luțaş, M. and Mihuț, I., 2018. Economie Europeană, ELRooo2 Economie europeană. Babeș-Bolyai University, unpublished.

6. Clarke, H., Goodwin, M. and Whiteley, P., 2016. Why Britain Votedfor Brexit: An Individual-Level Analysis of the 2016 Referendum Vote, [online] Available at: <https://blogs.kent.ac.uk/epop/files/2016/o7/ Clarke-Goodwin-and Whiteley.pdf $>$ [Accessed 8.08.2020].

7. Cooray,A. and Schneider,F.,2016. Doescorruption promoteemigration? An empirical examination. Journal of Population Economics, 29, pp.293-310. https://doi.org/10.1007/s00148-015-0563-y.

8. Congressional Research Service, 2018. The European Union: Ongoing Challenges and Future Prospects [online] Available at: <https://fas.org/sgp/crs/row/R44249.pdf> [Accessed 10.07.2019].

9. de Haas, H., 2011. The determinants of international migration: Conceptualising policy, origin and destination effects. IMI Working Papers Series, no. 32 [online] Available at: <https://www.migration institute.org/publications/wp-32-11> [Accessed 10.07.2019].

10. Eurobarometer Survey Parlemeter, 2018. Taking up the Challenge, commissioned for the European Parliament, [pdf] Available at: $<$ https://www.europarl.europa.eu/at-your-service/files/be-heard/ eurobarometer/2018/parlemeter-2018/report/en-parlemeter2018.pdf> [Accessed 15.08.2019]. 
Mihuț, LuȚaș, CÂlea, Narrowing the Gap in the European Union...

11. European Commission, 2019. Country Report Malta [online] Available at: <https://ec.europa.eu/info/sites/info/files/file import/2019-european-semester-country-report-malta_en.pdf $>$ [Accessed 17.08.2019].

12. European Commission, 2019. Migration and migrant population statistics [online] Available at: <https://ec.europa.eu/eurostat/ statistics-explained/pdfscache/1275.pdf $>$ [Accessed 20.08.2019].

13. Gallup, J.L., and Sachs, J., 1998. Geography and Economic growth, [pdf]Availableat: <https://pdfs.semanticscholar.org/be6b/a19beb16f 704834ccf63364d 3ae4d6d86440.pdf> [Accessed 20.08.2019].

14. International Monetary Fund, 2017. Seeking Sustainable Growth: Short-Term Recovery, Long-Term Challenges, [online] Available at: <https://www.imf.org/en/Publications/WEO/Issues/2017/09/19/ world-economic-outlook-october-2017> [Accessed 20.08.2019].

15. Lach, L. and Gurgul, H., 2012. Political instability and economic growth: evidence from two decades of transition in CEE. MPRA Paper, no. 37792 [online] Available at: <https://mpra.ub.unimuenchen.de/37792/> [Accessed 23.08.2019].

16. Moussis, N., 2003. Guide to European Policies, 9th revised edition. European Study Service.

17. North, D., 1991. Institutions, Institutional Change and Economic Performance. Cambridge: Cambridge University Press.

18. Ravenstein, E.G., 1885. The laws of migration. Journal of the Royal Statistical Society, 48, pp.167-227.

19. Samarasinghe, T., 2018. Impact of governance on economic growth. MPRA Paper, no. 89834 [online] Available at: <https:// mpra.ub.uni-muenchen.de/89834/1/MPRA_paper_89834.pdf> [Accessed 20.08.2019].

20. World Bank, 2020. Worldwide Governance Indicators. [online] Available at: <http://info.worldbank.org/governance/wgi/pdf/ pv.pdf $>$ [Accessed 20.08.2019].

21. World Economic Forum, 2019. The Global Risks Report 2019, 14th Edition [online] Available at: <http://www3.weforum.org/docs/ WEF_Global_Risks_Report_2019.pdf.> [Accessed 20.08.2019]. 